\title{
Damian Dobosz
}

Uniwersytet Jagielloński

DOI: $10.19915 / 1733-5779.20 .9$

\section{Konsumenci versus przedsiębiorcy w kontekście opłaty za obsługę posprzedażną}

\section{JEL classification: K00}

Słowa kluczowe: pytanie prejudycjalne, Trybunał Sprawiedliwości Unii Europejskiej, rzecznik generalny/adwokat generalny, Maciej Szpunar, obsługa posprzedażna, dyrektywa 2011/83, konsument, przedsiębiorca, taryfa podstawowa, połączenie, cel, orzeczenie, prawo, państwo

Keywords: preliminary question, the Court of Justice of the European Union, Advocate General, Maciej Szpunar, after-sales-service, directive 2011/83, customer, entrepreneur, the basic rate, call, purpose, judgment, law, state

Abstrakt: Artykuł podejmuje problematykę pytań prejudycjalnych skierowanych do Trybunału Sprawiedliwości Unii Europejskiej przez Landgericht w Stuttgarcie w sprawie Zentrale zur Bekämpfung unlauteren Wettbewerbs Frankfurt am Main e.V przeciwko Comtech GmbH, które na czas przygotowywania pracy doczekały się dotychczas opinii rzecznika generalnego Unii Europejskiej Macieja Szpunara. Najpierw dokonano analizy norm prawa wspólnotowego oraz niemieckiego znajdujących zastosowanie w zaistniałym stanie faktycznym. Meritum pytań sprowadza się do rozstrzygnięcia, czy zgodne z dyrektywą Parlamentu Europejskiego i Rady 2011/83/UE jest ustalanie przez przedsiębiorców wobec konsumenta odnośnie do umów zawartych poza lokalem przedsiębiorstwa lub na odległość opłat wyższych od kosztów zwykłego połączenia krajowego za wykonanie połączenia telefonicznego na specjalny numer celem otrzymania obsługi posprzedażowej. Następnie przedstawiono okoliczności faktyczne zaprezentowane przez adwokata generalnego oraz opatrzono je komentarzem wraz z dodatkowymi przemyśleniami. W dalszej części niniejszej pracy podjęto rozważania dotyczące możliwego zaistnienia pewnych szeroko rozumianych następstw prawnych. Końcowym przedmiotem opracowania jest przeprowadzona analiza kwestii wystąpienia ewentualnych skarg odszkodowawczych.

\section{Consumers versus entrepreneurs through the lens of a rate of the after-sales service}

Abstract: The article delves into preliminary questions to the Court of Justice of the European Union posed by the Landgericht in Stuttgart in the case Zentrale zur Bekämpfung unlauteren 
Wettbewerbs Frankfurt am Main e.V against Comtech GmbH. The author refers to a recent opinion of Maciej Szpunar, the Advocate General. The introductory part of the paper starts with the in-depth study of EU and Germany's regulations due to their application in the case at issue. The crucial issue is to decide whether arranging higher fees by entrepreneurs - as far as off-premises or distance contracts are concerned - is proceeding in accordance with the Directive of the European Parliament and the Council 2011/83/UE. Then the author adumbrates the factual circumstances presented by the Advocate General, comments them and - by detailed analysis, indicates staples of the case. Afterwards the author contemplates widely understood legal implications. Finally, compensation claims are taken into consideration.

\section{Przedmiot artykułu}

Inspiracją podjęcia tytułowej problematyki są pytania prejudycjalne skierowane do Trybunału Sprawiedliwości Unii Europejskiej (dalej: TSUE) przez Landgericht ${ }^{1} \mathrm{w}$ Stuttgarcie w sprawie Zentrale zur Bekämpfung unlauteren Wettbewerbs Frankfurt am Main e.V $V^{2}$ (dalej: Zentrale) przeciwko Comtech GmbH ${ }^{3}$ (dalej: Comtech), które na czas przygotowywania pracy doczekały się dotychczas opinii ${ }^{4}$ rzecznika (adwokata) generalnego Unii Europejskiej Macieja Szpunara (dalej: RG M. Szpunar). Meritum pytań sprowadza się do rozstrzygnięcia, czy zgodne z dyrektywą Parlamentu Europejskiego i Rady 2011/83/UE5 (dalej: dyrektywa 2011/83) jest ustalanie przez przedsiębiorców wobec konsumenta odnośnie do umów zawartych poza lokalem przedsiębiorstwa lub na odległość wyższych opłat od kosztów zwykłego połączenia krajowego za wykonanie połączenia telefonicznego na specjalny numer celem otrzymania obsługi posprzedażowej.

\section{Ramy prawne i stan faktyczny}

Celem uzyskania pełnego spektrum charakteryzowanej problematyki należy rozpatrzyć wyznaczone przez RG M. Szpunara ramy prawa unijnego oraz niemieckiego; $\S 312 \mathrm{a}$ ust. $5 \mathrm{BGB}^{6}$ :

${ }^{1}$ Sąd rejonowy.

2 Jest to jedno z największych niemieckich stowarzyszeń, które wykonuje swoje zadania przez m.in. doradztwo prawne, przyczyniając się do wspierania interesu handlowego swoich członków, w szczególności przedsiębiorstw, https://www.wettbewerbszentrale.de/de/institution/profil/ auftrag/ (dostęp: 16.11.2016).

3 Oferta przedsiębiorstwa dotyczy sprzedaży markowych produktów z zakresu smartfonów, komputerów, aparatów, telewizorów, sprzętu AGD, narzędzi itp.; https://www.comtech.de/ueberuns (dostęp: 16.11.2016).

4 Opinia Rzecznika Generalnego Macieja Szpunara przedstawiona w dniu 10 listopada 2016 r., ECLI:EU:C:2016:863.

5 Dyrektywa 2011/83/UE Parlamentu Europejskiego i Rady z dnia 25 października 2011 r. w sprawie praw konsumentów zmieniająca dyrektywę Rady 93/13/EWG i dyrektywę 1999/44/WE Parlamentu Europejskiego i Rady oraz uchylająca dyrektywę Rady 85/577/EWG i dyrektywę 97/7/ WE Parlamentu Europejskiego i Rady (Dz.U. L 304, s. 64).

${ }^{6}$ BGB - Burgerliches Gesetzbuch — niemiecki kodeks cywilny. Wersja opublikowana w Dzienniku Ustaw z 2.01.2002 (BGB1. I S. 42, ber. S. 2909, 2003 S. 738) ze zm. 
Postanowienie, w którego wyniku konsument zobowiązany jest do uiszczenia opłaty za to, że kontaktuje się z przedsiębiorcą $\mathrm{w}$ związku z pytaniami lub wyjaśnieniami dotyczącymi zawartej między nimi umowy za pomocą udostępnianego przez przedsiębiorcę w takich celach numeru, jest nieważne, jeśli należna za to połączenie opłata przekracza opłatę należną za zwykłe korzystanie z usługi telekomunikacyjnej. Jeżeli na mocy poprzedniego zdania postanowienie jest nieważne, konsument nie jest zobowiązany do uiszczenia opłaty za to połączenie również wobec operatora telekomunikacyjnego. Operator ten jest uprawniony do domagania się od przedsiębiorcy, który zawarł to nieważne porozumienie z konsumentem, uiszczenia opłaty za zwykłe korzystanie z usługi telekomunikacyjnej ${ }^{7}$.

Natomiast przepisy unijne znajdujące zastosowanie do tych okoliczności faktycznych to art. 4, 6 ust. 1 i 24 dyrektywy 2011/83. Artykuł 4 traktuje o zakazie wprowadzania i utrzymywania przez państwa członkowskie norm mających na celu zapewnienie innego poziomu ochrony interesów konsumentów. Artykuł 6 ust. 1 lit. f) wymaga udzielenia konsumentowi zawierającemu umowę na odległość lub poza lokalem przedsiębiorstwa informacji w sposób jasny i zrozumiały o koszcie korzystania ze środka porozumiewania się na odległość w celu zawarcia umowy, jeśli koszt ten obliczany jest w sposób inny niż na podstawie taryfy podstawowej. Natomiast ostatni omawiany art. 21 stwierdza, iż

[p]aństwa członkowskie zapewniają, aby w przypadku gdy przedsiębiorca posiada linię telefoniczną przeznaczoną do telefonicznego kontaktowania się z nim w sprawie zawartej umowy, konsument — kontaktując się z przedsiębiorcą - nie był zobowiązany do płacenia taryfy wyższej niż taryfa podstawowa. Akapit pierwszy pozostaje bez uszczerbku dla prawa dostawców usług telekomunikacyjnych do pobierania opłat za te połączenia.

Stan faktyczny dotyczy sytuacji, w której firma Comtech udostępniła na swojej stronie internetowej numer, pod którym to konsumenci mogli otrzymać obsługę posprzedażową. Numer ten miał prefiks 0180. Zgodnie z obowiązującą jednolitą taryfą cenową do obsługi serwisowej w Niemczech możliwe było, że konsument za zwykłe połączenie zostanie obciążony większą opłatą ${ }^{8}$. Zentrale uznał, że to działanie narusza $\S 312$ a ust. 5 BGB, który stanowi transpozycję art. 21 dyrektywy 2011/83. W ramach tego powództwa Zentrale podniósł, że udostępnienie linii telefonicznej obsługi posprzedażnej po cenie połączenia wyższej niż za zwykłe połączenie krajowe jest nieuczciwą praktyką handlową ${ }^{9}$. Comtech argumentował, że zgodnie z $§ 312$ a ust. 5 BGB w związku z art. 21 dyrektywy 2011/83 wymagane jest, aby przedsiębiorca nie uzyskiwał dochodu z wprowadzonej wyższej opłaty za połączenie. Zatem nie jest sprzeczna z prawem wyższa opłata za połączenie, jeżeli nie czerpie z tego korzyści przedsiębiorca.

W opinii sądu rejonowego w Stuttgarcie nie stoi w sprzeczności z przepisami sytuacja wprowadzenia przez przedsiębiorcę opłat wyższych niż za zwykłe połączenia, jeżeli nie czerpie z tego dochodów. Celem zastosowania $\S 312 \mathrm{a}$ ust. 5

7 Tłumaczenie BGB z opinii RG M. Szpunara.

8 Opłata z telefonu stacjonarnego miała wynosić 14 centów, a z telefonu komórkowego 42 centy. Zob. więcej https://www.comtech.de/ticket/index/sFid/5 (dostęp: 6.12.2016).

${ }^{9}$ Opinia Rzecznika Generalnego Macieja Szpunara, s. 4. 
BGB jest zapobieganie sytuacjom, w których przedsiębiorca osiąga zyski z opłat za kontaktowanie się z nim. Jej stawka może czynić zadość tylko kosztom ustanowienia takiej linii telefonicznej. A zatem konsument może płacić więcej aniżeli za zwykle połączenie. Przepis art. 21 dyrektywy 2011/83 nakłada na przedsiębiorcę, który udostępnia konsumentom celem wykonania połączenia linię telefoniczną, obowiązek nienakładania opłat wyższych niż taryfa podstawowa. Pojęcie to nie jest zdefiniowane w prawie unijnym. Konieczna jest więc wykładnia taryfy podstawowej. Mając na względzie wspomniane wątpliwości, sąd rejonowy we Stuttgarcie postanowił zawiesić postępowanie i przedłożyć wniosek o wydanie orzeczenia w trybie prejudycjalnym do Trybunału Sprawiedliwości Unii Europejskiej dotyczący interpretacji pojęcia taryfy podstawowej.

Istota problemu sprowadza się więc do niezdefiniowania używanego przez prawodawcę unijnego pojęcia taryfy podstawowej. Faktem jest, że przedsiębiorstwa często nakazują konsumentom płacić za połączenie stawkę wyraźnie wyższą niż wynikająca ze zwykłego połączenia. W Polsce coraz więcej konsumentów zawiera umowy abonenckie z firmami świadczącymi usługi telekomunikacyjne zapewniające nielimitowane rozmowy krajowe, niejednokrotnie z pakietem minut do wykorzystania w roamingu. Istnieje natomiast wiele firm, które celem uzyskania kontaktu telefonicznego z konsultantem zobowiązują konsumenta do opłacenia innej stawki niż wynikająca ze stawek operatora. Zazwyczaj związane to jest z koniecznością wykonania połączenia telefonicznego przez obywatela polskiego na numer telefoniczny zarejestrowany w innym państwie członkowskim. Praktykę ustanawiania wyższych kosztów często stosują linie lotnicze ${ }^{10}$, do obsługi klienta ustanawiające istotnie wyższe opłaty dla konsumenta niż te, które by poniósł za zwykle połączenie z numerem krajowym. Przedsiębiorcy nie zyskują z powodu stosowanych przez siebie instrumentów kontaktu, ponieważ są to koszta ustanowienia takiej linii telekomunikacyjnej. Natomiast przyglądając się sytuacji konsumenta, należy zauważyć, że jest on obarczany kosztem takiego mechanizmu. A zatem w takim układzie jest on w pozycji widocznie słabszej niż przedsiębiorca, z którym łączy go umowa zobowiązująca.

\section{Analiza okoliczności faktycznych przeprowadzona przez RG M. Szpunara}

RG M. Szpunar słusznie stwierdził, że pytania prejudycjalne sądu rejonowego w Stuttgarcie należy rozpatrzeć łącznie, ponieważ w gruncie rzeczy sprowadzają się do wątpliwości interpretacyjnych pojęcia taryfy podstawowej. Zgodnie ze stanowiskami rządów litewskiego oraz estońskiego przedsiębiorca nie powinien

10 Zob. więcej https://www.ryanair.com/pl/pl/Przydatne-informacje/centrum-pomocy/Czestozadawane-pytania/Kontakt/Skad-dzwonisz (dostęp: 3.12.2016) — cena za minutę rozmowy połączenia z konsultantem zaczyna się od 2,08 zł. 
nałożyć na konsumenta kosztów za połączenie wyższych od za zwykle połączenie krajowe. Istotnie, dyrektywa 2011/83 nie definiuje wspominanego pojęcia, w związku z tym RG M. Szpunar powołuje się na utrwalone orzecznictwo Trybunału Sprawiedliwości Unii Europejskiej. Można z niego wywnioskować, że w takiej sytuacji powinno się dokonać interpretacji wyrażenia zgodnie ze znaczeniem w języku potocznym, z jednoczesnym uwzględnieniem kontekstu, w którym jest ono użyte, celów uregulowania, którego jest częścią ${ }^{11}$.

W dalszych rozważaniach adwokat generalny zajmuje się znaczeniem taryfy podstawowej w języku niemieckim. Pojęcie to odnosi się do kosztu lokalnego połączenia ze zwykłym numerem, lecz niemiecki dorobek judykatury nie jest jednolity w tym zakresie. Wskazuje się w nim, że do taryfy podstawowej powinno się również zaliczyć koszty ustanowienia przez przedsiębiorcę linii telekomunikacyjnej. Można więc zauważyć, że właśnie na gruncie tych rozbieżności sąd niemiecki uznał konieczność przedstawienia pytania prejudycjalnego. RG M. Szpunar podnosi, że w każdym kraju analizowane pojęcie będzie cechowało odmienne znaczenie, dlatego celem zachowania jednolitości stosowania prawa unijnego nie możemy posługiwać się tylko wzorcem krajowym. „W razie rozbieżności pomiędzy różnymi wersjami językowymi tekstu prawa Unii dany przepis należy interpretować z uwzględnieniem ogólnej systematyki i celu uregulowania, którego stanowi on część" ${ }^{12}$. Niewątpliwie założeniem dyrektywy była ochrona konsumentów oraz harmonizacja przepisów w sposób pełny. W toku kolejnych rozważań RG M. Szpunar zastanawia się nad omawianym pojęciem w stosunku do wyrażeń go otaczających. Stwierdza, że art. 6 ust. 1 lit. f) dyrektywy 2011/83, dotyczący wymogów informacyjnych przy zawieraniu umowy na odległość lub poza lokalem przedsiębiorstwa, również używa pojęcia taryfy podstawowej. $\mathrm{Na}$ mocy tego przepisu przedsiębiorca musi powiadomić konsumenta o kosztach prowadzonej rozmowy w celu zawarcia umowy, jeśli odbiegają one od taryfy podstawowej. W związku z tym termin ten w tym przypadku oznacza koszt rozmowy ze zwykłym numerem w sieci lokalnej. Adwokat generalny słusznie dochodzi do wniosku, że jeśli taryfa podstawowa obejmuje takie znaczenie w art. 6 ust. 1 lit. f) dyrektywy 2011/83, to zarazem powinno się je rozumieć w zbieżnym zakresie w odniesieniu do art. 21 wspomnianej dyrektywy. Należy dodać, że taka interpretacja prowadzi do tożsamej wykładni dyrektywy, co pozwala w przyszłości uniknąć na tej linii nieporozumień. Ponadto istnieje domniemanie, iż racjonalny ustawodawca wspólnotowy nie tworzy siatki pojęć, która miałaby być w różnorodny

11 Wyrok z dnia 24 czerwca 2015 r., Hotel Sava Rogaška, C-207/14, EU:C:2015:414, pkt 25 i przytoczone tam orzecznictwo. Zob. więcej Opinia Rzecznika Generalnego Macieja Szpunara, s. 7.

12 Wyroki: z dnia 27 października 1977 r., Bouchereau, 30/77, EU:C:1977:172, pkt 14; z dnia 19 września 2013 r., Brey, C-140/12, EU:C:2013:565, pkt 74; z dnia 7 lipca 2016 r., Ambisig, C-46/15, EU:C:2016:530, pkt 48. Zob. więcej Opinia Rzecznika Generalnego Macieja Szpunara, s. 7. 
sposób wykładana. Cel dyrektywy 2011/83 zmierza bezsprzecznie do ochrony konsumentów, którą można zapewnić wyłącznie przez skuteczne zabezpieczenie ich interesów zgodnie z zasadą efektywności ${ }^{13}$.

W opinii RG M. Szpunara osiągnięcie celów dyrektywy 2011/83 może zapewnić tylko taka interpretacja pojęcia taryfy podstawowej, która nie odbiega od kosztów rozmowy ze zwykłym numerem w sieci lokalnej. Ponadto wskazuje on, że celem dyrektywy jest wysoki poziom ochrony konsumentów, co zapewnione jest również w prawie pierwotnym Unii Europejskiej - Traktacie o funkcjonowaniu Unii Europejskiej oraz Karcie praw podstawowych ${ }^{14}$. Rząd niderlandzki podniósł, iż $\mathrm{w}$ jego opinii niemieckie ustawodawstwo nie stoi w sprzeczności $\mathrm{z}$ art. 21 dyrektywy, konkludując, iż pojęcie taryfy podstawowej należy rozpatrywać jako stawkę za połączenie wraz z taryfą informacyjną. Przeciwnie twierdzi rząd estoński, uważając, że nie powinno dochodzić do sytuacji, w której to przedsiębiorca oczekuje od konsumenta opłaty za udzielenie informacji. Dodał też, że wspomniane oczekiwanie wynika ze stosunku zobowiązującego, w związku $\mathrm{z}$ tym konsument ma do niego niepodważalne prawo zgodnie także z zawartą umową. RG M. Szpunar wskazuje, iż słusznie wykazały rządy estoński i litewski oraz Komisja Europejska, że art. 21 dyrektywy 2011/83 dotyczy sytuacji, w której po zawarciu umowy konsument zwraca się do przedsiębiorcy w sprawie tej umowy, w szczególności w celu wyjaśnienia kwestii związanych z jej wykonaniem. Następnie adwokat generalny wywodzi, że wyższa opłata mogłaby zniechęcić do kontaktowania się z przedsiębiorcą konsumenta ze względu na kwestie oszczędnościowe. Należy także podkreślić, iż niejednokrotnie konsument spotyka się z dłuższym czasem oczekiwania na połączenie, kiedy dodatkowo uświadomi sobie wysokość opłaty za każdą minutę połączenia, częstokroć zaniecha kontaktu ze świadczeniodawcą. W tym pryzmacie RG M. Szpunar stawia tezę, iż „z ogólnej systematyki dyrektywy wynika niewzruszalne domniemanie, że telefoniczna obsługa serwisowa zawarta jest w zobowiązaniach stron, a więc $\mathrm{w}$ cenie zapłaconej już przez konsumenta"15. W przypadku wprowadzenia wyższej opłaty za połączenie mogłaby ona w pewnych przypadkach nawet przewyższyć koszt świadczonej przez przedsiębiorcę usługi.

13 TSUE powinien nadawać normom prawa wspólnotowego takie znaczenie, które pozwoli optymalnie osiągnąć cele prawodawcy unijnego - w tym przypadku głównym celem jest ochrona konsumentów. Zob. więcej S. Biernat, Zasada efektywności prawa wspólnotowego w orzecznictwie Europejskiego Trybunatu Sprawiedliwości, [w:] Studia z prawa Unii Europejskiej, red. S. Biernat, Kraków 2000, s. 71 n.

14 W motywie 3 dyrektywy 2011/83 przewidziano, iż ,art. 169 ust. 1 i art. 169 ust. 2 lit. a) Traktatu o funkcjonowaniu Unii Europejskiej (TFUE) stanowią, że Unia ma przyczyniać się do osiągnięcia wysokiego poziomu ochrony konsumentów poprzez środki, które przyjmuje na podstawie art. 114 TFUE”. Zob. więcej Opinia Rzecznika Generalnego Macieja Szpunara, s. 9.

15 Ibidem, s. 11. 
Zgodnie z konstatacją RG M. Szpunara dla ustawodawcy wspólnotowego za ratio przyjęto potrzebę wyeliminowania dodatkowych kosztów, którymi obarczani są konsumenci za kontakt z przedsiębiorcą. „Celem prawodawcy Unii była więc ochrona konsumentów przed zawyżonymi kosztami komunikacji naliczanymi za komunikowanie się przez telefon z przedsiębiorcą lub jego obsługą serwisową w sprawie zawartej już umowy"16. Wskazano również, że w wytycznych DG ds. Sprawiedliwości dotyczących dyrektywy 2011/83 przewidziano, iż „Spełnienie wymogu »taryfy podstawowej« wymaga od przedsiębiorców stosowania standardowych (geograficznych) numerów telefonów stacjonarnych lub komórkowych, które nie są objęte żadnym specjalnym systemem taryfowym"17.

Reasumując dotychczasową część rozważań, RG. M. Szpunar stwierdza, że pojęcie „taryfy podstawowej” obejmuje wszystkie koszty ponoszone przy korzystaniu z usług telekomunikacyjnych, i to bez względu na wysokość tych kosztów, odmienna interpretacja byłaby sprzeczna $\mathrm{z}$ celem regulacji, do którego zmierza prawodawca Unii. A zatem nie powinno się wliczać dodatkowych kosztów ustanowienia linii telekomunikacyjnej do taryfy podstawowej oraz należy ją rozumieć jako koszt za zwykłe połączenie krajowe. Odmienna interpretacja osłabiłaby skuteczność przepisów dyrektywy, która miała na celu ochronę konsumentów. RG M. Szpunar proponuje, aby Trybunał Sprawiedliwości Unii Europejskiej odpowiedział sądowi rejonowi w Stuttgarcie w następujący sposób:

Pojęcie „taryfy podstawowej” zawarte w art. 21 dyrektywy Parlamentu Europejskiego i Rady 2011/83/UE z dnia 25 października 2011 r. w sprawie praw konsumentów, zmieniającej dyrektywę Rady 93/13/EWG i dyrektywę 1999/44/WE Parlamentu Europejskiego i Rady oraz uchylającej dyrektywę Rady 85/577/EWG i dyrektywę 97/7/WE Parlamentu Europejskiego i Rady, należy interpretować w ten sposób, że kiedy w ramach obsługi posprzedażnej konsument kontaktuje się przez telefon z przedsiębiorcą, w sytuacji gdy ten ostatni udostępnił linię telefoniczną umożliwiającą konsumentom kontakt w sprawie zawartej umowy, to ponoszone przez konsumenta opłaty nie mogą przekraczać zwykłych opłat, które ponosiłby on za połączenie ze zwykłym numerem linii $\mathrm{w}$ sieci stacjonarnej (geograficznym) lub w sieci ruchomej ${ }^{18}$.

Należy więc przyjąć, że RG M. Szpunar opowiada się za jak najbardziej zawężoną wykładnią terminu „taryfa podstawowa” zamiarem zadośćuczynienia ochronie konsumentów w myśl zasady efektywności Unii Europejskiej. Z uwagi na konieczność zagwarantowania jednolitego stosowania prawa unijnego pojęcie taryfy podstawowej wszak nie mogłoby być odmiennie rozumiane. Taka wykładnia jest w konsekwencji całkowicie trafna, stwarzając sposobność otrzymania przez konsumenta informacji o zakupionej usłudze bez narażania się na dodatkowe koszty.

16 Ibidem, s. 13.

17 Zob. więcej wytyczne DG ds. Sprawiedliwości dotyczące dyrektywy 2011/83/UE, czerwiec 2014, s. 72.

18 Opinia Rzecznika Generalnego Macieja Szpunara, s. 14. 


\section{Dodatkowe przemyślenia dotyczące zastosowania dyrektywy}

Celem prawodawcy unijnego było ujednolicenie stosowania przepisów ochrony konsumentów w państwach członkowskich oraz zapewnienie ich właściwego stosowania. W szczególności w obszarze zawierania umów poza lokalem przedsiębiorstwa lub na odległość. Można byłoby rozważyć, czy w związku z tym rzeczywiście stosowanie pojęcia taryfy podstawowej zawężającej zgodnie z propozycją RG M. Szpunara jest zasadne. Jednak harmonizacja przepisów miała czynić zadość szeroko rozumianej ochronie konsumentów — zgodnie z motywem 3 dyrektywy 2011/83. Ponadto gdyby przyjęto, że taryfa podstawowa nie została zdefiniowana przez prawodawcę unijnego przepisami ją otaczającymi, o czym wspomina w swojej opinii RG M. Szpunar, należałoby przyjąć, że uniemożliwia to realizację motywu 6 dyrektywy 2011/83. Należy zauważyć, iż różnice, które powstałyby w rynku wewnętrznym, odbijałby się negatywnie na konsumentach oraz przedsiębiorcach zależnie od państwa członkowskiego. $\mathrm{W}$ jednym mielibyśmy do czynienia z sytuacją, w której przedsiębiorca może stosować wyższe opłaty za połączenie, natomiast $\mathrm{w}$ innym wręcz odmiennie. Wszystko zależałoby od interpretacji ustawodawcy oraz krajowego wymiaru sprawiedliwości. Takie rozwiązanie uniemożliwiałoby zachowanie jednolitości ochrony konsumentów na obszarze Unii Europejskiej.

Motyw 7 dyrektywy 2011/83 wskazuje, że wobec konsumenta mają być określone jednolite ramy regulacyjne, oparte na jasno zdefiniowanych pojęciach prawnych. Natomiast rezultatem takiej harmonizacji powinno być zlikwidowanie barier wynikających z rozdrobnienia przepisów oraz pełne wprowadzenie rynku wewnętrznego w tej dziedzinie. Należy więc rozważyć, czy pojęcie taryfy podstawowej jest jasno zdefiniowane. Niestety należy stwierdzić, biorąc pod uwagę pytania prejudycjalne zadane przez Sąd Rejonowy w Stuttgarcie, że jest zupełnie odmiennie. Interpretacja tego przepisu jest skomplikowana, ponieważ trzeba posłużyć się przepisami otaczającymi, żeby wywnioskować, jaki cel przyświecał ustawodawcy. Inaczej można byłoby dojść do konkluzji, że dysponujemy większą ilością znaczeń taryfy podstawowej. Niewątpliwie jednak głównym celem prawodawcy unijnego była harmonizacja przepisów i błędy legislacyjne nie mogą uniemożliwić interpretacji danych pojęć.

W mojej ocenie kolejnym argumentem potwierdzającym tezę Macieja Szpunara jest art. 7 ust. 4 dyrektywy 2011/83. Jasno z niego wynika, że w odniesieniu do umów zawieranych poza lokalem przedsiębiorstwa lub na odległość, jeżeli konsument wyraźnie zażądał świadczenia usług przez przedsiębiorcę w celu naprawy lub konserwacji, przedsiębiorca udziela konsumentowi informacji, o których mowa w art. 6 ust. 1 lit. b) i c), oraz informacji dotyczących ceny i sposobu, w jaki cena ma być obliczana. W sytuacji więc, w której konsument kontaktuje się $\mathrm{z}$ przedsiębiorcą celem powiadomienia na przykład o zaistniałym defekcie, nie może być nakładana na niego dodatkowa opłata za powiadomienie przed- 
siębiorcy o swoich prawach wynikających z zawartej umowy oraz za wezwanie do ich realizacji. Byłoby tak, gdyby przyjąć szeroką interpretację pojęcia taryfy podstawowej.

Należy przypomnieć też, że zgodnie z art. 26 dyrektywy 2011/83 jej charakter jest bezwzględnie wiążący. Zatem konsumenci nie mogą zrzec się przysługujących im uprawnień. Niezgodne z prawem unijnym są więc wszelkie dodatkowe postanowienia umowne, które określałyby koszty uzyskania obsługi posprzedażnej. Nawet wówczas kiedy zgodnie z art. 22 uzyskałyby zgodę konsumenta na dodatkową odpłatność za główne obowiązki przedsiębiorcy. A zatem dochodzi się do konkluzji, iż nie ma możliwości nałożenia opłat za uzyskanie obsługi posprzedażnej, ponieważ w każdym wypadku byłoby to niezgodne z przepisami dyrektywy i celami unijnego ustawodawcy.

\section{Następstwa ewentualnego wyroku Trybunału Sprawiedliwości Unii Europejskiej uwzględniającego opinię RG M. Szpunara}

Proponowane przez rzeczników generalnych odpowiedzi na pytania prejudycjalne są najczęściej powielane przez TSUE. Przeprowadzona analiza przepisów dyrektywy 2011/83 uprawdopodobnia realizację takiego samego scenariusza w odniesieniu do przedmiotowej sprawy. Następstwem takiego wyroku byłaby przede wszystkim konieczność dostosowania przez ustawodawcę krajowego - we wszystkich państwach członkowskich, których przepisy odbiegały od właściwego znaczenia taryfy podstawowej — przepisów krajowych tak, żeby uwzględniały rozstrzygnięcie TSUE. Taka zmiana istotnie przyczyniłaby się do polepszenia ochrony konsumenta, ponieważ nie będzie musiał obawiać się ponoszenia kolejnych kosztów za połączenie z przedsiębiorcą w celu uzyskania informacji o zawartej umowie. Ponadto powinna wzrosnąć również liczba konsumentów zawierających umowę na odległość w rozumieniu dyrektywy 2011/83 właśnie ze względu na niestosowanie dodatkowych opłat.

Firmy praktykujące pobieranie opłat za taką usługę będą musiały zmienić swój dotychczasowy modus operandi. Przedsiębiorstw posługujących się takimi rozwiązaniami jest nad wyraz wiele, szczególnie w odniesieniu do świadczenia usług transportu osób. Najlepszym przykładem są wspomniane już wcześniej linie lotnicze, które najczęściej wprowadzają bardzo wysokie, wręcz odstraszające konsumenta opłaty za kontakt telefoniczny. Ponadto także operatorzy kolejowi wysoko cenią udzielenie informacji przez telefon. Przykładem takiego przedsiębiorstwa są Przewozy Regionalne ${ }^{19}$, które pobierają opłatę w wysokości

19 Przewozy Regionalne powstały w 2001 r. Są największym pasażerskim przewoźnikiem kolejowym w Polsce. Udział firmy w rynku kolejowych przewozów pasażerskich wynosi około 30\%. Zob. więcej https://www.przewozyregionalne.pl/o-nas (dostęp: 6.12.2016). 
1,29 PLN/min ${ }^{20}$. Warto jednak odnotować pozytywne odstępstwa od tej reguły. Opłat za połączenie nie pobierają na przykład Polskie Linie Lotnicze LOT.

Konieczna jest też krótka refleksja co do tego, jak wyglądają opłaty za połączenie w innych państwach członkowskich. Należy zauważyć, że na przykład kontakt z liniami lotniczymi Ryanair w Wielkiej Brytanii jest całkowicie darmo$w y^{21}$. A zatem czy wprowadzanie takich wysokich opłat przez wielkie koncerny w pewnych częściach Europy — odstraszając skutecznie konsumentów od korzystania z nich - nie niweczy dążeń do jednolitego rynku wewnętrznego?

Należy zastanowić się, czy motyw 28 dyrektywy 2011/83 nie dopuszcza w niektórych przypadkach niestosowania przepisów dyrektywy, czyli także tych dotyczących taryfy podstawowej. Zgodnie z tym przepisem państwa członkowskie w celu uniknięcia obciążeń administracyjnych mogą postanowić o niestosowaniu niniejszej dyrektywy, gdy poza lokalem przedsiębiorstwa sprzedawane są towary lub usługi o niewielkiej wartości. Próg wartości należy ustalić na wystarczająco niskim poziomie, tak aby wyłączone zostały jedynie zakupy o niewielkim znaczeniu. Ponadto państwa członkowskie powinny mieć swobodę określania tej wartości, pod warunkiem że nie przekracza ona 50 EUR. Jeżeli konsument zawarł w tym samym czasie dwie umowy (lub więcej), których przedmiot jest $\mathrm{z}$ sobą powiązany, w celach stosowania tego progu powinien być uwzględniany całkowity ich koszt.

Ustawodawca polski skorzystał ze sposobności wyłączenia stosowania implementowanych przepisów dyrektywy 2011/83 zgodnie z art. 3 ust. 10 ustawy o prawach konsumenta ${ }^{22} \mathrm{w}$ odniesieniu do umów zawieranych poza lokalem przedsiębiorstwa, jeżeli konsument jest zobowiązany do zapłaty kwoty nieprzekraczającej 50 PLN. Prawodawca krajowy oczywiście zmieścił się w przedziale wskazanym prawem unijnym, które mówiło o kwocie nieprzekraczającej 50 EUR. Kwota opiewająca na sumę 50 PLN ma z pewnością także niewielką wartość. Natomiast przepis unijny traktuje, że ,[p]róg wartości należy ustalić na wystarczająco niskim poziomie, tak aby wyłączone zostały jedynie zakupy o niewielkim znaczeniu". Pułap określony jest przez polskiego ustawodawcę na wyraźnie niskim poziomie, jednak nie eliminuje on zakupów o niewielkim znaczeniu. Należy zaznaczyć, że w polskich realiach za kwotę 50 PLN można zakupić bilety kolejowy, a nawet lotniczy. Zatem uprawniona jest konkluzja, iż prawodawca krajowy nie realizuje w pełni dyrektywy 2011/83. Należy bowiem stwierdzić, że bilet lotniczy nie jest zakupem o niewielkim znaczeniu. Uważam jednocześnie, że pojęcie niewielkiego znaczenia ma wartość w rozumieniu aksjologicznym, określa zakup sensu stricto, który obiektywnie jest istotny dla konsumenta. Pojęcie to nie odnosi się również do kwoty, ponieważ jest odmienne od wyrażenia wartości

${ }^{20}$ Zob. więcej https://www.przewozyregionalne.pl/ (dostęp: 1.12.2016).

21 Zob. więcej https://www.przewozyregionalne.pl/o-nas.

22 Ustawa z dnia 30 maja 2014 r. o prawach konsumenta, Dz.U. 2014 poz. 827 ze zm. 
o niskim poziomie, użytego przez ustawodawcę wspólnotowego. Zakup biletu lotniczego najczęściej będzie miał natomiast większe niż „niewielkie znaczenie”, ponieważ podróż samolotem jest nadal dla wielu osób niezwykle ważnym przeżyciem. Można natomiast zakupić bilet lotniczy za cenę nieprzekraczającą nawet 50 PLN. Nie wspominając już o kwocie 50 EUR, wskazanej przez prawodawcę unijnego, za którą to możemy odbyć lot nawet i w dwie strony. Reasumując, niska kwota zakupu nie oznacza jego niewielkiego znaczenia, są to dwie odmienne przesłanki, które muszą być spełnione jednocześnie.

Powstaje zatem pytanie, jaka myśl przyświecała prawodawcy wspólnotowemu przez użycie pojęcia ,niewielkie znaczenie”. Uważam, że sam „,zagubił się” w siatce stworzonych pojęć, ponieważ niejednokrotnie może się zdarzyć, że kwota zakupu będzie poniżej wskazanego w dyrektywie 2011/83 pułapu kwotowego. Jednak będzie to zakup o istotnym znaczeniu dla konsumenta. Poza tym tworzenie sztucznego przedziału maksymalnego pułapu kwotowego jest zabiegiem nieudanym, prawodawca europejski wydaje się odrealniony, ponieważ kwota 50 EUR będzie miała wysoki próg wartości w niektórych krajach członkowskich, natomiast $\mathrm{w}$ pozostałych niski. Ponadto dla każdego konsumenta zakup może mieć istotne znacznie niezależnie od kwoty. Mimo więc dobrej intencji prawodawcy europejskiego, mającej na celu zmniejszenie biurokracji, zapis ten jest niejasny i w wielu sytuacjach stworzy problemy interpretacyjne. Jestem przekonany, że wraz z upływem czasu zaistnieją trudności dotyczące wykładni oraz zastosowania tego przepisu.

Niemniej jednak polski przedsiębiorca na podstawie przepisów krajowych będzie mógł nie zastosować dyrektywy 2011/83, a zatem i jej artykułu dotyczącego bezpłatnej obsługi posprzedażnej, jeżeli kwota transakcji nie przekroczy 50 PLN, zgodnie z ustawą o prawach konsumenta. Ponadto ustawodawca każdego z państw członkowskich może sam określić próg kwoty zwalniającej przedsiębiorców ze stosowania przepisów dyrektywy, jeśli nie przekraczają 50 EUR oraz mają niewielkie znaczenie.

\section{Odpowiedzialność odszkodowawcza w przypadku wyroku TSUE zgodnego z opinią RG M. Szpunara}

Tytułem wstępu do tego fragmentu rozważań należałoby przeanalizować motyw siódmy dyrektywy 2011/83, który stwierdza, że pełna harmonizacja przepisów powinna znacznie poprawić pewność prawa zarówno wśród konsumentów, jak i przedsiębiorców. Zarówno konsumenci, jak i przedsiębiorcy powinni mieć możliwość korzystania z jednolitych ram regulacyjnych, opartych na jasno zdefiniowanych pojęciach prawnych, regulujących niektóre aspekty umów zawieranych między przedsiębiorstwami.

Nie ulega wątpliwości, że ewentualny wyrok potwierdzający tezy RG M. Szpunara nie będzie utożsamiać pewności prawa dla przedsiębiorców. Sposób użycia 
terminu taryfy podstawowej nie był bowiem oparty na jasno zdefiniowanych pojęciach prawnych, ze względu na znaczne problemy interpretacyjne. Ustawodawca krajowy, a co za tym idzie przedsiębiorcy, miał w mojej opinii prawo użyć tego pojęcia $\mathrm{w}$ formie rozszerzającej, ponieważ brakowało jasnej jego definicji w dyrektywie 2011/83. Wykładnię należało przeprowadzić ze względu na cele dyrektywy oraz siatkę pojęć otaczających, co wywołało odmienne regulacje w państwach członkowskich.

Adwokat generalny nie poruszył w swojej opinii ewentualnej kwestii odszkodowawczej. Natomiast po wydaniu orzeczenia TSUE może się okazać, iż wiele podmiotów będzie mieć roszczenie w stosunku do przedsiębiorców o zwrot kwoty, którą zmuszeni byli uiścić za kontakt telefoniczny z obsługą posprzedażową. A zatem do kogo wówczas mogliby mieć regres przedsiębiorcy? Czy wobec państwa za wadliwą implementację dyrektywy 2011/83?

W celu uniknięcia możliwego chaosu wynikającego z orzeczenia TSUE uważam, że powinien on ograniczyć skutki swoich roszczeń. TSUE uznał bowiem kiedyś, iż stosując zasadę pewności prawa leżącą u podstaw wspólnotowego porządku prawnego, może ograniczyć ze skutkiem dla wszystkich zainteresowanych możliwość powoływania się na zinterpretowany przez niego przepis, celem podważenia stosunków prawnych zawartych w dobrej wierze ${ }^{23}$. Konieczne jest spełnienie dwóch przesłanek - dobrej wiary zainteresowanego i ryzyka poważnych konsekwencji. TSUE decydował się na taki krok niezwykle rzadko, m.in. wówczas gdy ze względu na znaczną liczbę podmiotów będących stroną stosunku prawnego powstałego $\mathrm{w}$ dobrej wierze na podstawie uregulowania uważanego za skuteczne i obowiązujące istniało ryzyko poważnych reperkusji finansowych, ponadto jeżeli osoby prywatne oraz władze krajowe działały niezgodnie z uregulowaniami wspólnotowymi - ze względu jednak na istnienie obiektywnej i istotnej niepewności odnośnie do zakresu przepisów wspólnotowych, do której przyczyniły się inne państwa członkowskie lub organy unijne, w szczególności Komisja Europejska ${ }^{24}$.

Rozpatrując wyznaczone przez TSUE przesłanki, należy stwierdzić, iż firmy działały w dobrej wierze, stosując rozszerzającą interpretację taryfy podstawowej, ponieważ czyniły zadość przyjętym rozwiązaniom prawnym przez ustawodawcę krajowego. Ponadto ewentualne orzeczenie TSUE może przynieść poważne konsekwencje wielu firmom, które stosowały zgodnie $\mathrm{z}$ wykładnią państwa członkowskiego taryfę podstawową sensu largo. Wiele podmiotów może wówczas zażądać zwrotu poniesionych opłat, które wcale nie trafiły wówczas do firm, tylko partycypowały w kosztach ustanowienia linii telekomunikacyjnej. A za-

${ }^{23}$ Zob. więcej wyrok z dnia 18 stycznia 2007 r., Maciej Brzeziński przeciwko Dyrektorowi Izby Celnej w Warszawie, C-313/05, ECLI:EU:C:2007:33.

${ }^{24}$ Zob. więcej J. Barcz, M. Górka, A. Wyrozumska, Instytucje i prawo Unii Europejskiej. Podręcznik dla kierunków prawa, zarządzania i administracji, Warszawa 2015, s. 428. 
tem może to doprowadzić do bankructw/upadłości przedsiębiorstw. Reasumując, należy stwierdzić więc, że obie przesłanki są spełnione. Dodatkowo można zauważyć, że w stanie faktycznym mielibyśmy do czynienia ze znaczącą liczbą stosunków prawnych zawartych na podstawie przepisów uznanych za skuteczne i obowiązujące. Ponadto państwa członkowskie oraz osoby prywatne działały niezgodnie $\mathrm{z}$ uregulowaniem wspólnotowym, jednak ze względu na jego niejasność, a co za tym idzie zaistniałe problemy interpretacyjne, było to $\mathrm{w}$ pewien sposób usprawiedliwione. Zatem istniała obiektywna niepewność odnośnie do zakresu przepisów unijnych. Reasumując, należy stwierdzić, że TSUE nie tylko może, lecz także powinien zgodnie z zasadą pewności prawa, a co za tym idzie również z zasadą efektywności, ograniczyć ze skutkiem dla wszystkich zainteresowanych możliwość powoływania się na zinterpretowany przez niego przepis w celu podważenia zawartych stosunków prawnych w dobrej wierze. Tylko takie rozwiązanie zabezpieczy interesy przedsiębiorców oraz uczyni zadość pewności obrotu prawnego.

W przypadku jednak nieograniczenia skutków swojego roszczenia przez TSUE należy przemyśleć, jakie instrumenty prawne pozostają przedsiębiorcom. Mają oni bowiem możliwość pozwać państwo członkowskie za wadliwą implementację dyrektywy. Zgodnie z trwale ustaloną linią orzecznictwa TSUE w przypadku badania odpowiedzialności odszkodowawczej ciążącej na państwie członkowskim trzeba zbadać spełnienie przesłanek ${ }^{25}$.

Najpierw należy sprawdzić, czy dyrektywa 2011/83 nakładała uprawnienie jednostce. Zgodnie z art. 21 państwo członkowskie powinno było czuwać, ażeby konsument - kontaktując się z przedsiębiorcą — nie był zobowiązany do płacenia taryfy wyższej niż taryfa podstawowa. Polska jako państwo członkowskie nie wykonała tego obowiązku.

Druga przesłanka, którą należy sprawdzić, to czy w konkretnej sprawie nastąpiło naruszenie prawa wspólnotowego uzasadniające odpowiedzialność odszkodowawczą państwa. Zatem konieczne jest rozważenie wszystkich elementów konkretnego stanu faktycznego. Należy wziąć pod uwagę, że stopień niejasności skomplikowania i niejasności norm był wysoki oraz naruszenie państw członkowskich nie było świadome. A zatem w mojej opinii błąd co do prawa był usprawiedliwiony, nie uzasadnia on więc odpowiedzialności odszkodowawczej ciążącej na państwie za wadliwą implementację dyrektywy 2011/83.

Ostatnia przesłanka zaistnienia związku przyczynowego między naruszeniem zobowiązania ciążącego na państwie członkowskim a szkodą ze względu na niespełnienie przesłanki drugiej nie podlega sprawdzeniu. TSUE powinien zatem

25 Sprawdzeniu zostały poddane przesłanki wyznaczone przez TSUE, m.in. zob. więcej wyrok z dnia 5 marca 1996 r. w sprawach połączonych C-46/93 i C-48/93 Brasserie du pêcheur SA a Bundesrepublik Deutschland oraz The Queen a Secretary of State for Transport ex parte: Factortame Ltd i inni. 
w sentencji wyroku podnieść, iż zasada odpowiedzialności odszkodowawczej państwa członkowskiego za naruszenie prawa wspólnotowego nie znajdzie tutaj zastosowania.

\section{Bibliografia}

Barcz J., Górka M., Wyrozumska A., Instytucje i prawo Unii Europejskiej. Podręcznik dla kierunków prawa, zarządzania i administracji, Warszawa 2015.

Biernat S., Zasada efektywności prawa wspólnotowego w orzecznictwie Europejskiego Trybunału Sprawiedliwości, [w:] Studia z prawa Unii Europejskiej, red. S. Biernat, Kraków 2000.

\section{Akty normatywne}

Ustawa z dnia 30 maja 2014 r. o prawach konsumenta, Dz.U. 2014 poz. 827 ze zm.

Dyrektywa 2011/83/UE Parlamentu Europejskiego i Rady z dnia 25 października 2011 r. w sprawie praw konsumentów zmieniająca dyrektywę Rady 93/13/EWG i dyrektywę 1999/44/WE Parlamentu Europejskiego i Rady oraz uchylająca dyrektywę Rady 85/577/EWG i dyrektywę 97/7/ WE Parlamentu Europejskiego i Rady (Dz.U. L 304, s. 64).

BGB - Burgerliches Gesetzbuch — niemiecki kodeks cywilny. Wersja opublikowana w Dzienniku Ustaw z 2.01.2002 (BGBl. I S. 42, ber. S. 2909, 2003 S. 738) ze zm.

\section{Orzeczenia}

Wyrok z dnia 27 października 1977 r., Bouchereau, 30/77, EU:C:1977:172.

Wyrok z dnia 5 marca 1996 r., w sprawach połączonych C-46/93 i C-48/93 Brasserie du pêcheur

SA a Bundesrepublik Deutschland oraz The Queen a Secretary of State for Transport ex parte:

Factortame Ltd i inni.

Wyrok z dnia 18 stycznia 2007 r., Maciej Brzeziński przeciwko Dyrektorowi Izby Celnej w Warszawie, C-313/05, ECLI:EU:C:2007:33.

Wyrok z dnia z dnia 19 września 2013 r., Brey, C-140/12, EU:C:2013:565.

Wyrok z dnia 24 czerwca 2015 r., Hotel Sava Rogaška, C-207/14, EU:C:2015:414.

Wyrok z dnia z dnia 7 lipca 2016 r., Ambisig, C-46/15, EU:C:2016:530.

\section{Źródła internetowe}

https://www.comtech.de/ticket/index/sFid/5.

https://www.comtech.de/ueber-uns.

https://www.przewozyregionalne.pl/.

https://www.przewozyregionalne.pl/o-nas.

https://www.ryanair.com/gb/en/useful-info/help-centre/faq-overview/contact-us/where-are-you-calling-from.

http://www.ryanair.com/pl/pl/Przydatne-informacje/centrum-pomocy/Czesto-zadawane-pytania/

Kontakt/Skad-dzwonisz/.

https://www.wettbewerbszentrale.de/de/institution/profil/auftrag/.

\section{Inne}

Opinia Rzecznika Generalnego Macieja Szpunara przedstawiona w dniu 10 listopada 2016 r., ECLI:EU:C:2016:863.

Wytyczne DG ds. Sprawiedliwości dotyczące dyrektywy 2011/83/UE, czerwiec 2014. 


\section{Consumers versus entrepreneurs through the lens of a rate of the after-sales service}

\section{Summary}

The analysis of law, aims and politics of the European Union which has been carried out within the article leads to conclusion that it is illegitimate in light of the EU law, in particular Directive $2011 / 83$, to charge consumers with additional costs for after-sales telephone services. Indeed aftersales telephone services comprise an intrinsic constituent of a contract relationship between an entrepreneur and a consumer. This approach has been confirmed and developed in lavish opinion of Advocate General. Others aspects of this work have been involved in a summary in each sections. 